\title{
FEDERAL COURT APPLICATION OF THE "DOING BUSINESS" TEST IN DIVERSITY CASES
}

$T_{\text {he Decision in Erie R.R. Co. v. Tompkins }}{ }^{1}$ has compelled the federal courts to determine whether state or federal law should be decisive of certain issues. One such issue which has caused particular difficulty in this respect concerns the amenability of a foreign corporation to the process of a federal district court. Obviously, in states with a test for "doing business" different from the federal test, ${ }^{3}$ the validity of service

${ }^{1} 304$ U.S. 64 (1938).

"See, note 5 DUKE B.J. I37 (1955) for a discussion of the various tests used by the courts to determine amenability of a non-resident to service of process.

${ }^{3}$ Since the decision in International Shoe Co. v. Washington, 326 U.S. 3 ro (1945), thirty-two state courts have considered the applicability of the new federal "doing business" test; a majority of these courts have followed the liberal view therein announced. Boyd v. Warren Paint \& Color Co., 254 Ala. 686, 49 So.2d 559 (1950); Duraladd Products Corp. v. Superior Court, 285 P.2d 699 (Cal. 1955); Klein v. Sunbeam Corp. 8 Terry 526, 94 A.2d 385 (Del. I952); District Grocery Stores, Inc. v. Brunswick Quick Freeze Co., 106 A.2d I34 (D.C. 1954); State v. Harrison, 74 So.2d 371 (Fla. 1954); Compania De Astral, S.A. v. Boston Metals Co., 205 Md. 237, I07 A.2d 357 (1954); Schilling v. Roux Distributing Co., 240 Minn. 71, 59 N.W.2d 907 (1953); Wooster v. Trimont Mfg. Co., 356 Mo. 682, 203 S.W.2d 4I I (1947); Suits v. Old Equity Life Ins. Co., 24I N.C. 483,85 S.E.2d 602 (1955); Grace v. Procter \& Gamble Co., 95 N.H. 74, 57 A.2d 619 (1948); S. Howes Co. v. W. P. Milling Co., 277 P.2d 655 (Okla. 1954); State v. Ford Motor Co., 208 S.C. 379, 38 S.E.2d 242 (1946); McDaniel v. Textile Workers Union of America, CIO, 36 Tenn.App. 236, 254 S.W.2d I (1952); James v. Consolidated Steel Corp., I95 S.W.2d 955 (Tex.Civ. App. I946); Eure v. Morgan Jones \& Co., I95 Va. 678, 79 S.E.2d 862 (1954); Smyth v. Twin State Improvement Corp., I I6 Vt. 569, 80 A.2d 664 (195 I); Thys v. State, 3I Wash.2d 739, I99 P.2d 68 (1948).

Other states have not expressly accepted the International Shoe decision, frequently because it would make no change in their definition of doing business. See Rodgers v. Howard, 215 Ark. 43, 219 S.W.2d 240 (1949), but see Gillioz v. Kincannon, 2 I 3 Ark. 1010, 214 S.W.2d 212 (1948), and American Farmers Ins. Co. v. Thomason, 217 Ark. 705, 234 S.W.2d 37 (1 950) (dissenting opinion); Travis v. Fuqua, I2 I Ind.App. 440, 97 N.E.2d 867 (195I); James v. Nashville, C. \& St.L. Ry., 310 Ky. 616, 22 I S.W.2d 449 (1949); Johnson v. El Dorado Creosoting Co., 7I So.2d 6I3 (La. 1954); Jet Mfg. Co. v. Sanford Ink Co., 330 Mass. 173, I12 N.E.2d (1952); Hershel Radio Co. v. Pennsylvania R.R. Co., 334 Mich. 148, 54 N.W.2d 286 (1952); Dillon v. AllenParker Co., 78 So.2d 357 (Miss. 1955). Contra: Davis-Wood Lumber Co. v. Ladner, 210 Miss. 863, 50 So.2d 615 (1951); American Casualty Co. v. Kincade, 219 Miss. 653, 69 So.2d 820 (I954); A.\&M. Trading Corp. v. Pennsylvania R.R. Co., 13 N.J. 516 , 100 A.2d 513 (1953). Compare Halloran y. Haffner, 25 N.J. Super. 241, 95 A.2d 921 (1953); Chaplin v. Selznick, 293 N.Y. 529, 58 N.E.2d 719 (1944).

Four states have expressly refused to accept the federal test. Perkins v. Benguet 
of process could depend on whether the federal or state rule was applied. ${ }^{4}$ The circuits, though divided, ${ }^{5}$ have leaned perceptibly toward applying state definitions of "doing business."

In Riverbank Laboratories v. Hardwood Products Corp., ${ }^{7}$ for example, an Illinois plaintiff instituted an action for unfair competition against a Wisconsin corporation which was not licensed to do business in Illinois, but was engaging in certain activity there. ${ }^{8}$ The Illinois

Consolidated Mining Co., x55 Ohio St. I 16,98 N.E.2d 33 (I95 I), rev'd, 342 U.S. 437 (1952); Pellegrini v. Roux Distributing Co., 170 Pa. Super. 68, 84 A.2d 222 (195I); Lutz v. Foster \& Kester Co., 367 Pa.-125, 79 A.2d 222 (1951); Western Gas Appliances, Inc. v. Servel, Inc., 257 P.2d 950 (Utah 1953).

"The extent to which it is incumbent upon the state courts to apply the federal test has received varied treatment. Judge Goodrich stated that as a result of the new federal test "the constitutional limitations on jurisdiction over a foreign corporation are not as strict as they were once thought to be. The consequence . . . is that it might be possible to extend ... [the present state laws] to some instances where the courts of that state have previously interpreted it to be inapplicable ... [but] it is the business of the federal court to follow the state court's construction . . until [it] announces a different rule." Pulson v. American Rolling Mill Co., I70 F.2d I93, 195 (1st Cir. 1948). "The broadest concept of doing business . . . does not automatically broaden state definitions of doing business. It merely permits such enlargement." Ackerley v. Commercial Credit Co., I I I F. Supp. 92, 98 (D.N.J. 1953). But some state courts feel bound by the International Shoe precedent. See State v. Harrison, 74 So.2d 371 (Fla. 1954); Schilling v. Roux Distributing Co., 240 Minn. 71, 59 N.W.2d 907 (1953); Davis-Wood Lumber Co. v. Ladner, 210 Miss. 863, 50 So.2d 615 (1951); Wooster v. Trimont Mfg. Co., 356 Mo. 682, 203 S.W.2d 411 (1947); Grace v. Procter \& Gamble Co., 95 N.H. 74, 57 A.2d 6I9 (I948).

" The split in the federal decisions has been widened by a distinction drawn between cases originally brought in the federal courts and cases brought in the state courts and later removed to the federal level. Professor Moore has rejected this distinction, flatly asserting that federal courts should exercise an independent judgment, both in actions originally instituted in the federal courts and in removed actions, concerning the validity of the service of process. 2 MOORE, Federal Practice Tf 4.25 (2d ed. 1948). For an excellent classification of the cases see, Kenny v. Alaska Airlines, Inc., 132 F. Supp. 838,845 (S.D. Cal. 1955).

${ }^{B}$ Many courts, however, have not even adverted to the problem. "Of the vast number of cases in the federal courts that have considered the problem of doing business, [since Erie ø. Tompkins] probably the majority of the cases have launched into a discussion as to whether the foreign corporation was doing business in the state without consideration as to whether state or 'general' federal law should be applied to the problem. ..." Kenny v. Alaska Airlines, Inc., 132 F. Supp. 838, 844 (S.D. Cal. 1955).

${ }^{7} 220$ F.2d 465 (7th Cir. 1955), cert. granted, 24 U.S.L. WEEK 3082 (U.S. Oct. 11 , 1955) (No. 66).

${ }^{8}$ As shown by depositions taken, the defendant bore all the expenses of maintaining a Chicago office, through which solicitations of orders were made. Defendant had its corporate name on the office door, and was listed in the Chicago telephone directory and in the office building lobby. Defendant shippped merchandise from Wisconsin into - Ilinois continuously over a long period of years in amounts exceeding $\$ 100,000$ an- 
district court granted plaintiff a temporary injunction. ${ }^{9}$ But the court of appeals for the Seventh Circuit reversed on jurisdictional grounds, ${ }^{10}$ holding that state rather than federal law should determine whether a foreign corporation was "doing business" within the state.

Generally, courts have taken one of two approaches to the cases. On the one hand, some have relied upon Rule 4(d) (7) of the Federal Rules of Civil Procedure, which provides that the process of a federal district court shall be served upon foreign corporations "in the manner prescribed by the law of the state."11 This language, of itself, is said to be broad enough to require the application of state law to determine the amenability of a foreign corporation to a district court's process. ${ }^{12}$ It is quite apparent from the context of Rule $4(\mathrm{~d})(7)$, however, that the phrase should not have that effect. ${ }^{13}$ Imparting to these words a

nually, and it had paid license royalties for the use of plaintiff's trade name, prior to its expiration, of over $\$ 3,000$ per month. In addition, defendant had made written agreements with other Illinois corporations for installation of its products. Its office manager investigated complaints, all relating to the installation and servicing of the defendant's product in the Illinois area.

${ }^{\circ}$ Injunctive relief is the appropriate remedy for a corporation in Illinois where another has made exploitive use of its corporate name. Baldassano v. Accettura, 336 IIl.App. 445, 84 N.E.2d 336 (1949). See ILL. ANN. STAT. c. 134, $\$$ I34.04(a) (Jones Supp. 1953).

${ }_{220}$ F.2d 465,468 ( 7 th Cir. 1955). The court speaks in terms of "venue" when it refers to service of process to gain "jurisdiction."

${ }^{11}$ FED. R. CIv. P. 4 (d) (7).

${ }^{13}$ The argument that the word "manner" used in Federal Rule 4 (d) (7) also includes a state's concept of "doing business" was adopted in Bomze w. Nardis Sportswear, Inc. I65 F.2d 33, 35 (2d Cir. 1948) (opinion by Judge Learned Hand), and in Pulson v. American Rolling Mill Co., 170 F.2d 193, 194 (1st Cir. 1948) (opinion by Judge Goodrich). However, the rule in the Bomze case, supra, was limited by one court to removal cases, since the language of the decision "seems to imply that New York decisions are not relevant when a case is initiated in a federal court." Satterfield v. Lehigh Valley R.R. Co., I 8 F. Supp. 669, 671 (S.D.N.Y. 1955). Nevertheless, a line of decisions has developed since the Bomze-Pulson rationale was announced, in which the "same concept used by Judge Goodrich [and Judge Learned Hand] has been relied upon." Kenny v. Alaska Airlines, Inc., ${ }_{32}$ F. Supp. 838, 844 (S.D. Cal. 1955). Cases supporting this view include: Roberts v. Evans Case Co., $2 \times 8$ F.2d 893, 895 (7th Cir. x955); Lone Star Package Car Co. v. Baltimore \& Ohio R.R. Co., $2 \times 2$ F.2d 147, I 53 (5th Cir. 1954); Schmidt v. Esquire, Inc., 210 F.2d 908, 9x5 (7th Cir. x954); Partin v. Michaels Art Bronze Co., 202 F.2d 54x (3d Cir. x953) (opinion by Judge Goodrich). In a concurring opinion in the Partin case, Judge Biggs stated that "it is not apparent whether the [majority] decision is based on a construction of $[4(d)(7)]$ providing, inter alia, for a method of service of process under state practice, or strictly on the doctrine of Erie R.R. v. Tompkins." Id. at 545 .

${ }^{13}$ For an examination of the difficulties that might arise if Rule ${ }_{4}(d)(7)$ is as broad as these authorities contend, see Note, 30 IND. L.J. 324, 330 et seq. (1955). 
jurisdictional meaning would be attributing an undue significance to a rule which was clearly intended to regulate only the more mechanical aspects of actual service of process. ${ }^{14}$

On the other hand, the majority of federal courts, in determining which law should apply, have followed the familiar "substance-procedure" analysis of the Erie decision. ${ }^{15}$ It is seldom, however, that the courts have supported their conclusions by more than a superficial examination of the problem. ${ }^{16}$ The conflict in the decisions is further aggravated by the fact that plausible arguments can be developed on both sides.

${ }^{14}$ That the intended breadth of the word "manner" as used in Federal Rule 4(d) (7) is restricted to the mechanics of process is emphasized by a comparison of that particular section with other provisions contained in the entire Rule 4. See: Scholnik v. National Airlines, Inc. 219 F.2d 115, x20 (6th Cir. 1955); Gravely Motor Plow \& Cultivator Co. v. H. V. Carter Co., I93 F.2d 158, 159 (9th Cir. 1951); Kenny v. Alaska Airlines, 132 F. Supp. 838,843 (S.D. Cal. 1955); Harris v. Deere \& Co., 128 F. Supp. 799, 802 (E.D.N.C. 1955); West v. Cincinnati, N.O. \& T.P. Ry. Co., 108 F. Supp. 276, 278 (E.D. Tenn. I952); Allegue v. Gulf \& South American S.S. Co., I03 F. Supp. 34, 35 (S.D.N.Y. 1952); Moore v. Atlantic Coast Line R.R. Co., 98 F. Supp. 375, 378 (E.D. Pa. 1951); Hall v. Gulf South Utilities, 96 F. Supp. 351, 353 (S.D. Miss. 195x). Favell-Utley Realty Co. v. Harbor Plywood Corp., 94 F. Supp. 96, 97 (N.D. Cal. 1950); 2 MOORE, FEDERAL Practice (2d ed. 1948) compare T 4.18 with ๆ 4.42.

${ }_{15}$ The Erie mandate requires matters of substantive law in the federal courts to be based upon state law, reserving procedural matters for the federal courts.

${ }^{18}$ For example, see Lone Star Package Car Co. v. Baltimore \& Ohio R.R. Co., 212 F.2d 147, 153 (5th Cir. 1954); Steinway v. Majestic Amusement Co., I79 F.2d 68x, 682 (Ioth Cir. 1949). Similarly, the courts that have applied federal law have done so without real analysis. Professor Moore contends that "[w] $[$ hether a forcign corporation or other business is doing business in a state is a matter of general, not local, law." 2 MOORE, FEDERAL Practice $\{4.25$ (2d ed. 1948), and cases cited. Accord: French v. Gibbs Corp., 189 F.2d 787 (2d Cir. 1951); Satterfield v. Lehigh Valley R.R. Co., 128 F. Supp. 669, 670-67I (S.D.N.Y. 1955), and cases cited therein; Nyberg v. Montgomery Ward \& Co., 123 F. Supp. 599, 602 (W.D. Mich. 1954); Ackerly v. Commercial Credit Co., 111 F. Supp. 92 (D.N.J. 1953); Pike v. New England Greyhound Lines, 93 F. Supp. 669, 671 (D. Mass. 1950); Leakley v. Canadian Pacific Express Co., 82 F. Supp. 906, 908 (D. Alaska 1949); Hinchcliffe Motors Inc. v. WillysOverland Motors, Inc., 30 F. Supp. 580 (D. Mass. 1939); Hedrick v. Canadian Pacific Ry. Co., 28 F. Supp. 257 (S.D. Ohio 1939 ). For a discussion of the difficulties raised by a categorical application of rules such as the Erie rule, see, Pound, Mechanical Jurisprudence, 8 Colum. L. REv. 605, 608, 610 (1908); Hynes v. New York Central R.R. Co., 231 N.Y. 229, 235, I3I N.E. 898, 900 (1921). Admittedly, the "'substantive' shades off by imperceptible degrees into the 'procedural' and the 'line' between them does not 'exist,' to be discovered merely by logic and analysis, but is rather to be drawn so as best to carry out" the functions of the forum without undue hindrance or inconvenience. Cook, "Substance" and "Procedure" in the Conflict of Laws, 42 YALE L.J. 333, 343 (1933); Tunks, Categorization and Federalism: "Substance" and "Procedure" After Erie Railroad v. Tompkins, 34 ILL. L, REv. 271 (1939). 
A fundamental policy consideration underlying the substance-procedure rule is that the perhaps fortuitous availability of a federal court should not enable a litigant to achieve there a "substantially different result" from that which would be reached in the state courts. ${ }^{17}$ Applying this criterion to the question at hand, it could be argued that state law should test the amenability of a foreign corporation to process, since, if federal law were applied, the local plaintiff would be receiving relief unavailable to him in his state court. ${ }^{18}$

Counterbalancing this analysis, however is the argument that even the prospect of a litigant's achieving a "different result" should not justify an obstruction to the orderly operation of federal courts by application of state law. ${ }^{19}$ The federal definition of "doing business" is generally thought to be determinative of the service of process issue in cases where the district court jurisdiction rests on a federal question. ${ }^{20}$ If such is the case, a decision that state definitions should apply in diversity cases would give rise to a serious administrative problem. In an

${ }^{17}$ Cohen v. Beneficial Industrial Loan Corp., 337 U.S. 541, 556 (1949); Woods v. Interstate Realty Co., 337 U.S. 535, 538 ( 1949 ); Ragan v. Merchant's Transfer \& Warehouse Co., 337 U.S. 530, 532 (1949); Angel v. Bullington, 330 U.S. I83, I9 I (x947); Guaranty Trust Co. v. York. 326 U.S. 99, rog (1945).

${ }^{18}$ The Court in the Riverbank case purported to apply the decisional law of Illinois in rendering its opiuion. See Bull \& Co. v. Boston \& Maine R.R. Co., 344 Ill. II, I75 N.E. 837 ( I93 I) ; Booz v. Texas \& Pacific Ry. Co., 250 Ill. 376, 95 N.E. 460 (I9II). Were the Riverbank case to coine up today in Illinois, the decision would be different because of ILL. ANN. STAT. c. 104 $\S_{\text {r } 04.017}$ (1955). This statute provides, inter alia, for service upon any "person" regardless of his citizenship if any business is transacted within the state. This liberal trend "is sufficiently established so that its general adoption seems to be but a matter of tine." Comment, 50 Nw. U.L. Rev. 425, 43 I, (I955). See: Md. ANN. CODE art. $23, \$ 88, \$ 92$ (r951); N.C. GEN. STAT. $\$ 55-145$ (effective July I, 1957); VT. STAT. tit. 9, c. $72 \S_{1562}$ (1947). Compare discussion in note 9 supra.

${ }^{10}$ If a particular issue is greatly enmeshed with the innerworkings of the federal courts, its rules, functions, and purposes, the court ought not be required to depart substantially from its rules of procedure and should be allowed, in such cases, to determine its own jurisdiction without being impeded by state law. See Stephenson v. Grand Trunk Western R.R. Co., I so F.2d 40I (7th Cir. r940).

${ }^{20}$ It seems apparent that "when enforcing state rights in diversity cases, a federal court acts as a state court; but when enforcing a federal right, it may be independent of state rules." Note, 59 Harv. L. Rev. 966, 972 (r 946); Note, 34 Cornell L.Q. 494, 520 (1949). See also: Association of Westinghouse Salaried Employees v. Westinghouse Electric Corp., 348 U.S. 437; 46r (I955) (concurring opinion); Freres v. United States, 340 U.S. 135, 142 ( 1950 ); United States v. Standard Oil Co., 332 U.S. 301, 305 (1947); Holmberg v. Armbrecht, 327 U.S. 392, 395 (1945); Jerome v. United States, 3 I 8 U.S. 101, 104 (1943); D'oench, Duhme \& Co. v. Federal Deposit Ins. Corp., 315 U.S. 447,456 (1942); Deitrick v. Greaney, 309 U.S. 190 (1940). 
action wherein the jurisdictional statement in the complaint alleged both diversity and a federal question, the district court would be compelled to pass on the merits of the latter allegation prematurely in order to determine which test of "doing business" is applicable.

In addition, a federal venue statute ${ }^{21}$ is perhaps relevant to this consideration in so far as it provides that, for venue purposes, a "corporation may be sued in any judicial district in which it is ... doing business." Obviously, to determine whether a corporation is "doing business" for purposes of the federal venue statute, the federal test would be applied. ${ }^{22}$ If, then, state law is invoked to determine the validity of a district court's service of process on foreign corporations, instances would arise where that court would lack jurisdiction, when, at the same time, its venue would be proper-despite the fact that both venue and jurisdiction would be dependent on the same factor. It has been urged that the particular venue statute and the general operation of federal courts would be better served if this irregularity were eliminated. ${ }^{23}$

It appears, then, that neither line of decision is without some surface appeal. Of the two, however, the argument supporting the application of state law, depending as it does on the "different result" analysis, seems somewhat less satisfactory. That the plaintiff in Riverbank, assuming his claim were valid, could get relief in any state court in which jurisdiction over the defendant could be acquired would indicate

21 "A corporation may be sued in any judicial district in which it is incorporated or licensed to do business or is doing business, and such judicial district shall be regarded as the residence of such corporation for venue purposes." 62 STAT. 935 (1948), 28 U.S.C. $\$ 1391$ (c) (1952). In Freiday v. Cowdin, 83 F. Supp. 516 (S.D.N.Y. 1949), the court stated that $\$ 1391$ (c) enlarged both the vulnerability of foreign corporations to suit in the federal courts and their opportunities of access to such courts. See Hadden v. Barrow, Wade, Guthrie \& Co., 105 F. Supp. 530 (N.D. Ohio 1952). Contra, Chicago \& Northwestern Ry. Co. v. Davenport, 94 F. Supp. 83 (S.D. Iowa r950). See also Hart \& Wechsler, The Federal Courts and The Federal System 959 (1953).

${ }_{22}$ That state law cannot control the venue of federal courts, see Mississippi Pub. Corp. v. Murphree, 326 U.S. 438, 442 (1946); Steel Motor Service, Inc. v. Zalkc, 212 F.2d 856, 858 (6th Cir. 1954); McCoy v. Saler, 205 F.2d 498, 499 (3d Cir. 1953), cert. denied, 346 U.S. 872 (1953); State Public School Bldg. Authority v. Maryland Casualty Co., 127 F. Supp. 902, 904 (D. Pa. 1955).

${ }^{23}$ This irregularity has been criticized as leading to "a developing confusion resulting from a uniform federal interpretation of 'doing business' for purposes of venue existing alongside of 48 varying interpretations of what is sufficient doing business to permit service of process." Barrett, Venue and Service of Process in the Federal CourtsSuggestions for Reform, 7 VAND. L. REv. 608, 619 (1954). 
that his substantive cause of action was not at all affected by the fact that no such personal jurisdiction was available in the Illinois courts. This, in turn, suggests that the issue of the district court's personal jurisdiction is actually unrelated to the body of facts which together comprise plaintiff's right to relief. ${ }^{24}$ From this it follows that application by the federal court of its own "doing business" test would not, then, in any way add to the legal right asserted by plaintiff. Rather, it would only serve to enable the district court to enforce that right against this defendant. That the "result would differ" from the result to be anticipated in a similar action in the state court is only superficially relevant, since the "different result" derives only from the broader personal jurisdiction of the district court, and not from an alteration of plaintiff's substantive right to relief. Such a change in result does not appear to contravene the policy underlying Erie R.R. Co.v. Tompkins.

Decisions like Woods v. Interstate Realty Co., ${ }^{25}$ elaborating on this policy, are probably not inconsistent with the above analysis. ${ }^{26}$ There, a state statute closed the Mississippi courts to any foreign corporation doing business in Mississippi without appointing a resident agent for service of process. Plaintiff, a foreign corporation which had made no such appointment, brought suit in the Mississippi federal district court against a resident of the state, for breach of contract. 'The United States Supreme Court, reversing the court of appeals, held that, since no right

24 "Jurisdiction," as the term is used in the context of this substance-procedure embroglio, is hardly involved with the operative facts which compose a plaintiff's cause of action, as are other factors such as burden of proof and presumptions [Cities Service Oil Co. v. Dunlap, 308 U.S. 208, 212 (1939)], conflict of laws [Klaxon Co. v. Stentor Electric Mfg. Co., $3 I_{3}$ U.S. 487,496 (r940)], contributory negligence [Palmer v. Hoffman, 318 U.S. I09, 117 ( 1943 )], and the statute of limitations [Guaranty Trust Co. v. York, 326 U.S. 99, x Io (1945)], all of which are generally determined by recourse to state law, regardless of whether they are considered matters of procedure or substance. See Sullivan, Federal Rules of Civil Procedure, § I005 at 34 I (I949). ${ }_{25} 337$ U.S. 535 (I 949 ).

${ }^{20}$ Cohen v. Beneficial Industrial Loan Corp., 337 U.S. 54 I (1949), held that a state's conditioning of a stockholder's personal suit against a corporation upon his posting of a bond was a valid exercise of the plenary power of a state, and could not "be disregarded by the federal court as a mere procedural device." Id. at 556. Ragan v. Merchants Transfer $\&$ Warehouse Co., 337 U.S. 530 (x 949 ), held that the state statute of limitations governed in a federal suit based on diversity of citizenship, since ". . . that cause of action is created by local law." Id. at 533. In Angel v. Bullington, 330 U.S. 183 ( 1947 ), a Virginia resident was denied recovery for a deficiency judgment in the North Carolina courts because a state statute flatly barred such actions. Subsequently, asserting diversity of citizenship he attempted to sue on the same claim in a federal district court. The Supreme Court held that he could not recover, since a ". . . federal court ... cannot give that which [a state court] has withheld." Id. at I 92. 
of action could be asserted by this plaintiff in the Mississippi courts, the federal courts, under Erie, were similarly disabled from giving relief. But the viability, locally, of the right asserted by the plaintiff in Woods was substantially less than that of the plaintiff in Riverbank. While in Woods the right itself survived, the Mississippi statute deprived the state courts of jurisdiction over the subject matter of plaintiff's cause of action, pointedly indicating the state's policy against enforcing that "right." In Riverbank, on the other hand, the right is fully enforceable; the state courts have jurisdiction over the subject matter, but lack jurisdiction over the defendant. For the federal court to give relief in the Woods case would plainly interfere with an avowed state policy; but there would be no such interference if the district court were to assert jurisdiction in Riverbank. Furthermore, if, in a Woods situation, the defendant were a resident of the state whose courts are closed to the plaintiff, the federal district court might be the only tribunal in which the plaintiff could serve the defendant with process. It would be a clear violation of the Erie rationale to allow the plaintiff to enforce a state right of action in a federal court when there might be no other court in the country to which he could resort.

Taking into account the venue statute, the possible administrative difficulties which could arise if the "doing business" test were different in diversity and federal question cases, and the apparently limited validity of the arguments supporting an application of state law, the better disposition of the Riverbank case would probably be to apply the federal "doing business" test. 